be definitely proved that it did. He says: "If any part of the small intestine becomes unduly full the mesentery of that portion is stretched into an irregular wavy fan-shape and although the coil cannot be straightened it is made to assume a gentle curve at the distal end of its mesentery." And again further on he says, "If there are several distended ends together the gut at the end of each coil must bend sharply" -in other words, become kinked. What exactly he means by the distal end of the mesentery is not clear, for the whole length of the intestines are attached at the distal end of the mesentery; probably he means at the end of that particular coil of intestine, for he says, "the flow of the contents round this curve is easy." Unless Mr. Malcolm means that the fact that there are several distended coils determines the sharp bending the two statements are contradictory, for if distension causes a gentle curve that is a very different thing from a sharp bend. Distension to any great extent certainly causes a sharp bend and that whether the intestines are within or without the abdominal cavity so long as they are attached to the mesentery.

Then Mr. Malcolm says that "when a piece of bowel which has not lost its peristaltic power distends it must push the ends of its coils against the boundaries of the peritoneal cavity formed by the abdominal walls and any piece of gut which is paralysed and inert must be bent at a sharp angle to an active piece of distended bowel with which it is continuous." But when a coil of bowel distends its ends will tend to kink exactly in proportion to the amount of distension, whether there are a few inches of inert gut at its end or not. It is not the inertia of the gut which determines the kinking, it is the degree of distension. If $\mathrm{Mr}$. Malcolm means that if the few inches of inert gut occur, not where kinking from over-distension would under any circumstances occur but at the middle rather than at the end of a coil of intestine as it lies across the abdominal cavity, then I fail to see why it should kink at all. Mr. Malcolm also says that he cannot agree with me that the formation of a fistula is an unreasonable method of treatment if the nipped bowel is paralysed but the bowel above retains its peristaltic function. If Mr. Malcolm could prove that the paralysis of the few inches of nipped bowel did really cause an actual obstruction, then clearly the reasonable treatment would be to open the bowel above or resect the severely damaged part, but he does not prove it. $\mathrm{My}$ contention was that drainage of the intestine as usually employed, after the relief of a mechanical obstruction, in order to empty the paralysed and distended ends was an unreasonable proceeding.

I am, Sirs, yours faithfully,

Bristol, May 3rd, 1903. CHARLES A MORTON.

\section{THE LONDON COUNTY COUNCIL AND THE APPOINTMENT OF OFFICIAL PATHOLOGISTS.}

\section{To the Editors of THE LANCET.}

SIRS,-In THE LANCET of May 2nd, p. 1251, is an annotation dealing with the meeting held at the Middlesex Hospital in referenc to the London County Council and pathologists. In regard to your remarks I should like to point out, first, that the meaning which you attach to "delegate" is a secondary one and true only in a limited sense. The proper signification of "delegate" is wider and more general, though in some circles, as trades unions, \&c., it has the acceptation you impart to it. Secondly, in regard to the voting. The proceedings began by the chairman reading letters from King's College Hospital and Westminster Hospital which clearly stated the positions of both these corporations. My part in the business was therefore at an end and I remained only out of curiosity to hear what more could possibly be said on the subject.

After some discussion Dr. C. J. Cullingworth moved a harmless, innocuous resolution which allowed every body to do as it pleased. Up to this point I had no intention of taking part in the proceedings, but when a tyrannical and socialistic amendment was moved-an amendment which had the object of preventing individual action, was hostile to freedom of thought, and amounted to a declaration that certain institutions regarded themselves as the judges of what was right and proper for the rest of the profession-I felt that I ought to protest. No objection was taken to my voting and in connexion therewith I may mention that the institutions located in Smithfield and the Borough had with a prudent thoughtfulness provided themselves with two representatives apiece, though the votes of these extra arbitri morum were disallowed. Thirdly, I think that if some 12 months ago the Council had approached the profession informally just to ascertain the feeling of the latter in regard to this important question before it was brought forward publicly much trouble might have been saved.

May 5th, 1903. $1 \mathrm{am}$, Sirs, yours faithfully,

\section{UNIVERSITY OF LONDON : SENATORIAL ELECTION.}

\section{To the Editors of THE LANCET.}

SIRS, - It has not hitherto been the custom that candidates for election to the Senate of the University of London should issue an address to the members of Convocation, and we do not apprehend that Sir Thomas Barlow will, in the present instance, depart from so laudable a practice.

We therefore ask you to allow us to make known through your journal that Sir Thomas Barlow, by his long and wellsustained service to the University continues, in our opinion, to merit the strong support of all those graduates who have at heart the development of the University in the interests of true education.-We are, Sirs, yours obediently,

Charles A. Ballance. A. ERnest Sansom.

J. Mrtchell BRUCE.

NoRMan DALTON.

MaRY SCHARLIEB.

A Pearce Gould,

F. DE HAVILLAND HALL

J. A. NUNNELEY.

F. G. Pentose.

SIDNEY PHILLIPS.

FRED. T. ROBERTS.

T. MaRKHAM SKerRITT. Frederick TAYLOR.

H. J. WARING.

JUDSON BURY.

AlFred Hy. CARTER.

RUSHTON PARKER. May 6th, $19: 3$.

\section{THE ROYAL COLLEGE OF SURGEONS IN IRELAND.}

\section{To the Editors of THE LANCET.}

SIRs.-It may be in the recollection of your readers that some time ago correspondence of mine appeared in the columns of 'THE LANCET relating to an examination for the Fellowship of the above College. The circumstances were, to my mind, so unusual, from the fact more particularly that of 40 candidates examined at four examinations 39 passed and that the College never denied having broken its charters, by-laws, and Fellowship regulations at these examinations, that $I$ felt no diffidence whatever in giving publicity to the fact of my rejection. It may further interest your readers to know that not having sufficient confidence in the system of examination I refused a re-examination proffered me through my solicitor and subsequently returned the certificate of primary examination which $I$ had, in common with a few hundred other Licentiates and third-year students, obtained without examination for $£ 1010 \mathrm{~s}$. on the occasion of Her late Majesty's visit to Ireland. This latter I did on the ground that $I$ was examined in a subject which according to its regulations the primary certificate exempted me from. "The College whereupon acknowledged "the resignation" of my primary "examination" (sic). The President, Yice-President, and Council subsequently refusing to return me my fees I sued them in the Recorder's Court, Dublin, for their recovery.

Although the College had feed a strong Bar in the persons of the Solicitor-General for Ireland and Mr. W. G. Jefferson, an eminent junior, no cross examination was made nor was any other defence attempted except the stock one of a rejected candidate's "grievances." Indeed, the College frankly owned up to the violation of its charters and by-laws through its secretary to council swearing that so far as the Fellowship examination went it had been doing so for 14 years-that, in short, so many candidates now entered for this examination it would be impossible to provide the "three or more" council witnesses required. Considering that each candidate paid $£ 265 s$. for the privilege of examination it apparently never occurred to the College to pay the charter witnesses for attending to their charter duties. The Recorder, while adwitt ng the examination to be " a voidable" one, referred the case without prejudice to the superior courts.

To expend a few hundred pounds in endeavouring to 